GEOFIZIKA VOL. $33 \quad 2016$

DOI: $10.15233 / g f z .2016 .33 .3$

Original scientific paper

UDC 551.468.1

\title{
Modelling origin and transport fate of waste materials on the southeastern Adriatic coast (Croatia)
}

\author{
Martina Tudor ${ }^{1}$ and Ivica Janeković ${ }^{2,3}$ \\ ${ }^{1}$ Meteorological and Hydrological Service of Croatia, Zagreb, Croatia \\ ${ }^{2}$ Rudjer Bošković Institute, Zagreb, Croatia \\ ${ }^{3}$ The University of Western Australia, School of Civil, Environmental and Mining Engineering \\ \& UWA Oceans Institute, Crawley, WA, Australia
}

Received 6 July 2015, in final form 5 January 2016

\begin{abstract}
In this study we analysed meteorological and oceanographic conditions that lead to the waste deposition along the southeast Croatian coast during the second half of November 2010. We used available in situ measurements, atmospheric products (reanalysis, remote sensing) as well as atmosphere and ocean numerical models. The measured meteorological data reveal that an intensive rainfall event occurred from 7 till 10 November 2010, over the parts of Montenegro and Albania. It was followed by a substantial increase of the river water levels indicating a possibility of flash floods, capable of splashing the waste material into a river and after to the Adriatic Sea (or to the sea directly). The currents that could bring this waste to Croatian coast are likely intensified by the strong wind from southeast direction. In order to test these two hypotheses we set a number of numerical drifter experiments with trajectories initiated over southeast Adriatic during the intensive rainfall events following their path in space and time. The numerical drifter trajectory experiments that resulted with drifters reaching the right position (southeastern Adriatic coast) at exact time the waste was observed were initiated on 00:00 and 12:00 UTC of 10 November 2010 during the mentioned high precipitation event.
\end{abstract}

Keywords: Adriatic, drifter trajectory, numerical models, flash flood

\section{Introduction}

On the 21 November 2010, a dramatic waste accumulation has been widely reported by public media (web news agencies, television, radio, daily papers) at the southeastern coast of Croatia, particularly area of Pelješac Peninsula; islands Mljet, Korčula and Lastovo as well as in numerous inlets and beaches northwest of Dubrovnik (see map of the area in Fig. 1) and Dugi Otok several days later. The heaps of waste were composed mostly of plastic packages, glass bottles, 


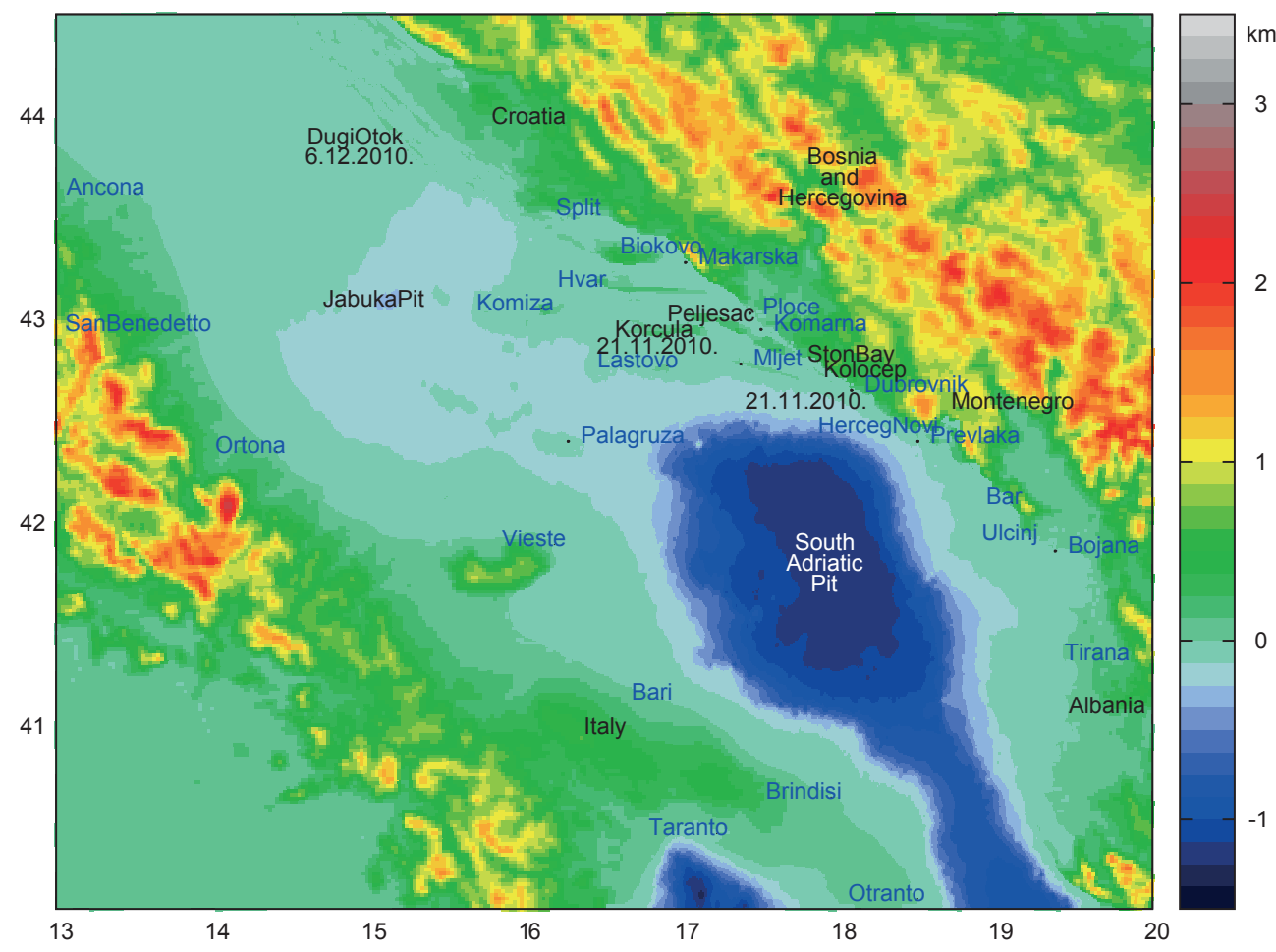

Figure 1. The South Adriatic region with locations of meteorological stations used in this study. The shaded background represents terrain height and bathymetry in metres according to the scale on the right side. State borders, coastlines and islands are drawn as black lines and rivers as blue lines. The "Bojana" mark shows position of the point where Bojana River enters the Adriatic Sea (this is also the border between Montenegro and Albania on the coast).

clothes and other typical floating municipal garbage while labels suggested that some part of the waste arrived from Albania.

Numerical modelling studies that examine how a floating entity reached a certain position by means of atmosphere and sea driven currents have been done before (Beg Paklar et al. 2008; Döös et al. 2011; Liu and Weisberg, 2011). The subjects range from explanation of how floating sweet potato reached Polynesia from South America (Montenegro et al., 2008), spread of oil spills such as the one following the Deepwater Horizon disaster has received more attention (for a collection of articles see http://deep waterhorizon.nooa.gov/) as well as the floating debris that was washed to the sea by tsunami following the Tohoku $9 \mathrm{Mw}$ earthquake on 11 March 2011 (see http://www.marinedebris.noaa.gov/).

This study describes a possible chain of events that lead to waste accumulation on beaches in southeast Croatia. It is not unusual that a few pieces of waste reach Croatian coast in a late autumn, however the event was several orders of magnitude larger than any other in previous years (according to the local 
officials, there were no reports in the media). This study documents the atmospheric, hydrological and ocean processes that preceded the accumulation of waste, including intense precipitation and flash-flood events in Albania and a presence of a favourable ocean current, enhanced by winds, that transported the waste into the beaches of southeast Croatia.

The Adriatic Sea is a narrow sea, connected to the Mediterranean by the Otranto Strait. Bathymetry varies over the basin, the northern part mean depth is $35 \mathrm{~m}$, the central region reaches $280 \mathrm{~m}$ in Jabuka Pit and the southern region $1200 \mathrm{~m}$ in the South Adriatic Pit (SAP).

The Adriatic Sea surface flow is predominately of cyclonic orientation (Cushman-Roisin et al., 2001) with distinct current regime of East Adriatic Current (EAC) flowing northwest along the eastern coast characterized with salty and warm water from the Ionian Sea. During the rain seasons EAC is further intensified with the outflow of the Albanian rivers creating region of fresh water (ROFI) dynamics (Burrage et al., 2008, 2009). In the central region the sea surface flow typically bifurcates east of the Palagruža Sill e.g. (Wolf and Luksch, 1887) enhancing the cyclonic circulation in the southern Adriatic (Artegiani et al., 1997; Horton et al., 1997). On the other side of the Adriatic Sea there is a Western Adriatic Current (WAC) holding fresher and colder water along the western coast.

On the land, the area is surrounded by Apennines in the west, Dinaric Alps and high mountains of Montenegro and Albania along eastern coast while on the northern coast reaches low and flat Po Valley. Those mountains have a strong effect on the air flow and atmospheric dynamics (Mesinger and Strickler, 1981) and consequently define the sea current response as well.

Mediterranean cyclones often traverse the area (Horvath et al., 2008, 2009). However, cyclones often form in the Genoa Bay, at the northwest (Mesinger and Strickler, 1981) traverse the Tyrhennian Sea and continue to the east possibly supporting cyclone development and intensification in the Adriatic Sea at the east and Ionian Sea at the south (Alpert et al., 1990) including twin cyclones (Lionello et al., 2006).

The intensive atmospheric dynamics in the area also supports strong wind (Horvath et al., 2011; Bajić et al., 2007; Branković et al., 2008) development with the most severe and gusty wind from northeast named bura (see Grisogono and Belušić, 2009, for a review), as well the local wind from southeast referred as jugo (Jurčec et al., 1996). Strong bura or strong jugo can last for several days inducing strong response in the Adriatic Sea (Kuzmić et al., 2006; Dorman et al., 2006). Onset, duration and spatial distribution of wind strength is controlled by an interaction of the synoptic and/or mesoscale forcing with local topography (Ivatek-Šahdan and Tudor, 2004; Pasarić et al., 2007; Tudor and Ivatek-Šahdan, 2010). Jugo blows along shore, it is steady and relatively warm wind related to a Genoa cyclone (Jurčec et al., 1996) or mesoscale cyclone above northern Adriatic (Brzović and Strelec Mahović, 1999; Brzović, 1999). 
Southern Adriatic region is characterized with warm and dry summers and mild and wet winters (Zaninović et al., 2008). The area receives abundant precipitation amounts as Crkvice in Montenegro holds the maximum measured on the European continent (Magaš, 2002). Precipitation can be further intensified by increased aerosol concentration (Koren et al., 2012) from the Sahara Desert.

Annual river run-off distribution for the Albanian rivers usually varies for an order of magnitude during the year with two pronounced peaks, one in November and another in January. Bojana River collects the water flowing from Drim River and Skadar Lake and flows into Adriatic along the border between Albania and Montenegro.

The largest lake in the region, the Skadar Lake, is filled by river Morača and Crnojevića in Montenegro and drained into Bojana River (the name is Bojana in Montenegro and Buna in Albania). Bojana River also receives Drim River as a major tributary on the way to the Adriatic Sea. Drim (Drim in Montenegro, Drin in Albania) River powers 3 hydroelectric power plants in Albania. Downstream it splits into two flows, the smaller one reaches the Adriatic Sea directly, and the larger part flows into Bojana River.

The quality of simulated currents on the ocean surface depends on the wind field. Wind field over Adriatic is variable in both space and time, and depends on surrounding topography. Events with strong and severe wind are better forecast in high resolution NWP models (Ivatek-Šahdan and Tudor, 2004; Branković et al., 2008; Tudor and Ivatek-Šahdan, 2010). It is worth to say that wind forcing, when pronounced, dominate over all other forcing contributions and dynamically shape the sea surface current system found in the Adriatic Sea. The surface wind jets and wakes of the bura wind have a profound effect on the surface currents (Orlić et al., 1994; Pullen et al., 2003), while jugo wind is well known to influence WAC flow reversals (Orlić et al., 2007; Poulain et al., 2004). It is therefore important to force the ocean model with a high resolution wind field that resolves high resolution wind features developed due to interaction of large scale dynamics with local mountains.

Section 2 describes the geographical characteristics of the studied area, meteorological and oceanographic conditions, measured data and models used in this paper. Results of the analysis of weather patterns using available measured data and results of model simulations are presented in Section 3, followed by discussion and conclusions in Section 4.

\section{Measured data and models}

\subsection{Measured data}

In order to asses the weather situation we used available remote sensing data and in situ measurements. For the meteorological part we used SYNOP, 
climatological and rain-gauge measurements from Croatia, Montenegro, Italy, Greece and Macedonia. At the time of the event (November 2010) there were no in situ measured data available from Albania through standard meteorological network, the data from the airport did not contain measurements of precipitation. The hydrological analysis was based on the water level measurements on relevant major rivers in Montenegro and Macedonia used to confirm intensive precipitation as a possible cause of the flush flood event.

Remote sensing data, used in this study, originate from Meteosat Second Generation (MSG), specifically from The EUMETSAT Network of Satellite Application Facilities (NWC SAF, products available on the http://www.eumetrain.org/). To estimate the convective rainfall rate and precipitating clouds we used derived fields from the NWC SAF products focused on studied area and time, and rain-gauge measurements and TRMM rainfall data. The NWC SAF precipitating clouds (PC, Thoss, 2012) field provides precipitation probabilities and the convective rainfall rate in $\mathrm{mm} /$ hour (CRR, Rodiriguez and Marcos, 2012) is computed assuming that clouds being both high and with a large vertical extent are more likely to induce rain (see http://www.nwcsaf.org/ for more details). CRR gives estimate of intensive rainfall from convective clouds, but $\mathrm{PC}$ is useful estimate of rainfall from other types of clouds (e.g. nimbostratus). Satellite derived precipitation data are used as provided from the Tropical Rainfall Measuring Mission (TRMM, Huffman et al., 2007), in particular we used the diurnal accumulated precipitation data from the 3B42 product and 3-hourly precipitation intensity data from 3B40RT product.

Precipitation can be enhanced by the presence of aerosols (Koren et al., 2012). The two sets of aerosol data presented in this study are the aerosol optical thickness (AOT) from Moderate Resolution Imaging Spectroradiometer (MODIS, Remer et al., 2008) aboard Aqua satellite and Ozone Monitoring Instrument aboard NASA's Earth Observing System (EOS) Aura satellite (OMI, Torres et al., 2002; Veihelmann et al., 2007). The wind over the sea surface derived from Metop ASCAT (Bentamy et al., 2012; Bentamy and Croizé-Fillon, 2012) was used to evaluate 10-meter wind field from the meteorological model.

\subsection{Atmospheric model-ALADIN}

The numerical weather prediction (NWP) model data used in this study originate from the operational $8 \mathrm{~km}$ resolution forecast runs using ALADIN limited area model (Aire Limitée Adaptation Dynamique développement InterNational, ALADIN International Team, 1997) with a specific local 3-D-var data assimilation (Stanešić, 2011). In autumn 2010, operational forecast run twice per day up to $72 \mathrm{~h}$ in advance starting from 00:00 and 12:00 UTC analyses. The model forecast in $8 \mathrm{~km}$ resolution used initial and boundary conditions from global model ARPEGE (Action de Recherche Petite Echelle Grande Echelle, Cassou and 
Terray, 2001) run operationally in Meteo France. The operational high-resolution dynamical adaptation (Ivatek-Šahdan and Tudor, 2004) provides forecast of $10 \mathrm{~m}$ wind adapted to local and upstream topography in $2 \mathrm{~km}$ resolution. Unfortunately, this method provides only wind field at high resolution, but not the other meteorological variables needed to force the ocean model. The meteorological model $10 \mathrm{~m}$ wind field is obtained by vertical interpolation from the lowest model level (17 m above sea, see Geleyn, 1988 for more details).

In order to simulate the mesoscale characteristics and development of the low pressure field, a $2 \mathrm{~km}$ resolution forecast using the non-hydrostatic set-up of the ALADIN model and the full parametrization set, including radiation, microphysics and convection schemes (Tudor and Ivatek-Šahdan, 2010) was used to model the state of the atmosphere. The high-resolution forecast uses scale selective digital filter initialization (Termonia, 2008) and no data assimilation to initialize the model fields. It is coupled to the ALADIN $8 \mathrm{~km}$ resolution with $3 \mathrm{~h}$ interval. This might be insufficient to prevent the fastest of the meteorological features to enter the domain unnoticed by the lateral boundary coupling procedure (Tudor and Termonia, 2010) and possibly miss or undersample a storm rapidly entering the domain through the lateral boundaries. Since the southern Adriatic is not very far from the southern lateral boundary of the high resolution domain, model could have underestimated a storm arriving from south through Otranto strait, however this would be a short duration event related to a flash flood but too short to affect the sea currents substantially.

ALADIN uses sea surface temperature (SST) from the initial file of the global model it is coupled to. The field is constant during a single forecast (24 hours in this case) but varies from one forecast run (starting from different analysis) to another. The global model ARPEGE uses SST from the Mercator Ocean forecasting system (www.mercator-ocean.fr), and SST was at the time constant during one forecast run, but also changes in the next analysis.

\subsection{Ocean model-ROMS}

The ocean dynamics as a response to the atmospheric forcing was computed using Regional Ocean Modelling System (ROMS, Shchepetkin and McWilliams, 2005) numerical model. ROMS model belongs to free surface, Boussinesq and hydrostatic approximation models that solves primitive equations on curvilinear finite difference grids. Model was forced with ALADIN meteorological model data (10 $\mathrm{m}$ wind, $2 \mathrm{~m}$ temperature and relative humidity, sea level pressure, rainfall rate, short wave radiation and cloud fraction), climatological values for the Adriatic river run-offs and open boundary values with daily temperature, salinity, currents and sea level information from AREG (INGV) Mediterranean model. The advection scheme for tracers (temperature and salinity) is based on multidimensional positive definite advection transport algorithm - MPDATA 
(Smolarkiewicz and Margolin, 1998) while for momentum on $3^{\text {rd }}$ order upwind scheme. More details of model implementation for the Adriatic Sea are described in (Janeković et al., 2010). ROMS model time step was 120 s while outputs of needed current fields were stored every hour.

The sea surface currents, responsible for waste transport, are computed using $2 \mathrm{~km}$ resolution ROMS ocean model and were used for virtual drifter trajectory simulations. Drifters are set to the surface layer, without vertical dynamics, ensuring representation of floating waste material. For computing numerical drifter trajectories, we used Roms OFFline Floats (ROFF) package (Carr et al., 2008). An offline version of the ROMS Lagrangian module uses existing netcdf output files from ROMS to advect numerical floating drifters. Using this software is less computer demanding than running ROMS for each release of floats. The software is available at http://web.atmos.ucla.edu/capet/Myresearch/my_research_floats.html. The waste content assumed floating items, so it's movement was computed as virtual floating drifters, released in southeast region of the Adriatic Sea. The computation of the trajectories of the drifters stopped when they reached coastline for the first time. This allowed accumulation of drifters.

\section{Results and discussion}

The meteorological conditions during October and November 2010 in southern Adriatic included several episodes of intensive precipitation that initiated flash floods in Montenegro and Croatia (there were no reports available for Albania). A flash flood event could have washed the waste to the sea (or first to a lake or a river that would eventually take it to the sea). There was no rainfall data from Albania available through standard international data exchange so remote sensing data and NWP model data were used to estimate which intensive precipitation events (if any) could have initiated a flash flood there. The high precipitation events that could have initiated flash flood in the area are identified by combination of in-situ and remote sensing data.

\subsection{Meteorological conditions}

According to the available rain-gauge measurements, 6 hourly PC and CRR fields, TRMM rainfall data and operational model forecasts, there were several heavy rainfall events in the month preceding 21 November 2010 that could have caused flash floods in the area of southeast Adriatic coast and inland. We identify those events as four episodes: 23-25 October (E1), 2-3 (E2), 8-10 (E3) and 17-18 November 2010 (E4).

The large scale synoptic conditions responsible for meteorological setup are described using ERA Interim (Dee et al., 2011) re-analysis fields. It turns out that on 24 October 2010, low pressure system entered western Mediterranean 
from Atlantic, deepened and formed a cyclone, centred over Genoa bay. The next day the pressure decreased further and the associated southern wind strengthened from northern Africa to Adriatic causing intensive rainfall over the eastern Adriatic coast (E1). The cyclone moved southeast on 26 and initiated severe bura wind first on northern Adriatic and later spread over the whole Adriatic Sea by 27 October 2010. An ensemble of trajectories initiated over southeast Adriatic on 12:00 UTC, 25 October 2010 were used to test if this severe rainfall event was the one that flushed the waste to the sea. The results of these trajectory computations are described later in the text (as experiment 2 in Sect. 3.3.1)

Another cyclone from the 1 till the 4 November 2010 (E2) moved from the Genoa bay southeastward, causing strong jugo wind over the Adriatic Sea (Fig. 2). The rainfall was the most intensive over the northern Italy and central Adriatic region with most of the rainfall above the Adriatic Sea. Northern Adriatic received more than $100 \mathrm{~mm}$ of precipitation within $24 \mathrm{~h}$, while the rain was weak in the southeastern region of our interest (Fig. 3). Consequently, E2

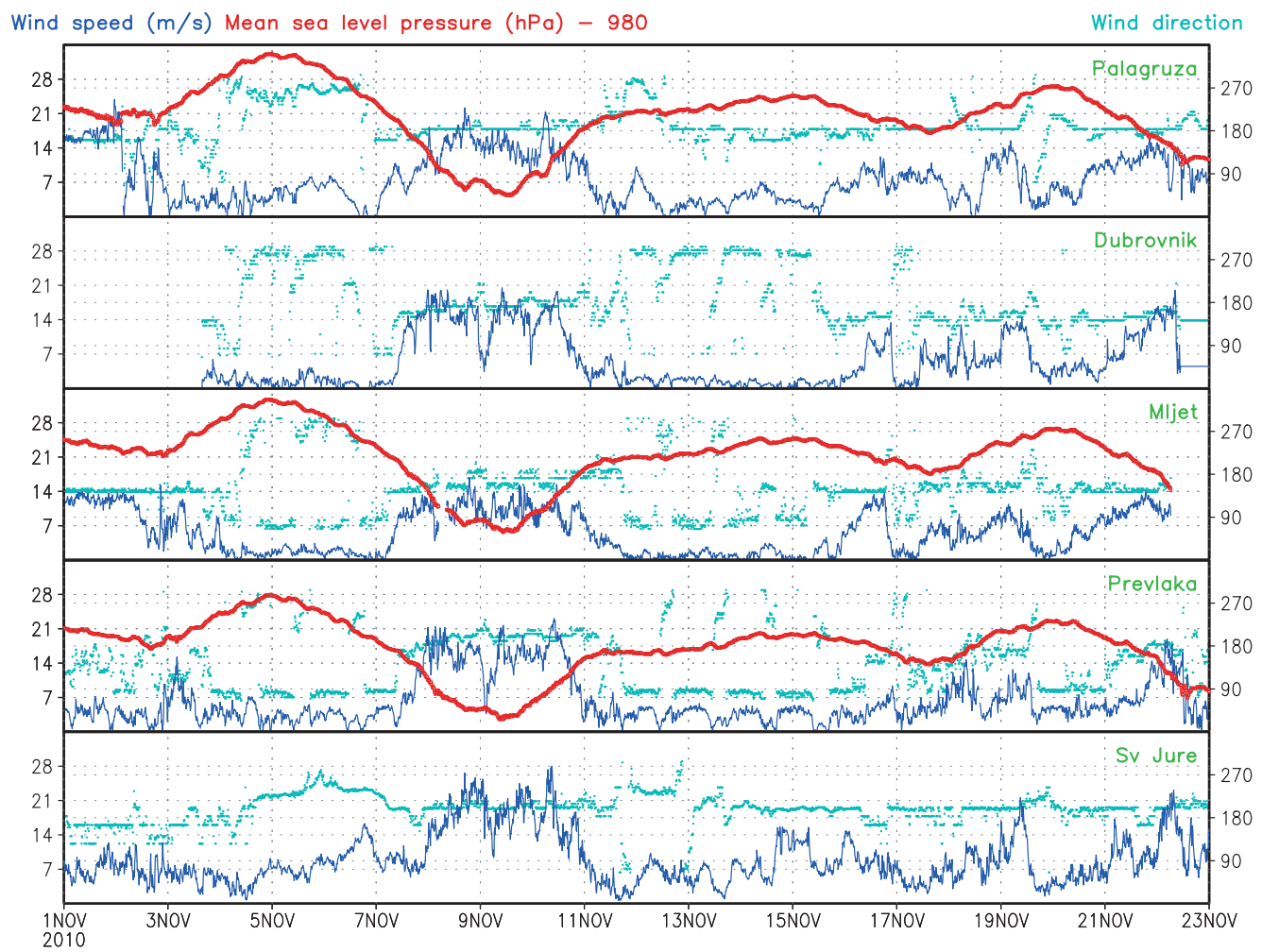

Figure 2. Measured wind speed (dark blue, scale on the left) and mean sea level pressure (red) reduced by $980 \mathrm{hPa}$ (to fit the scale on the left) and wind direction (light blue, in degrees from north clockwise, scale on the right) for October and November 2010. Sv. Jure is marked as Biokovo in Fig. 1. 
case was omitted from further analysis as was too weak to initiate a flash flood in southeast Adriatic. In the following days, meteorological situation was stable with weak pressure gradient, low wind as well high pressure over western Mediterranean inducing moderate winds from northwest.

The synoptic situation weather changed again in the period from 7 till 10 November 2010 (E3), dominated by a large scale cyclone (Fig. 3) that arrived from the Northern Atlantic causing sirocco wind over Mediterranean (the colour
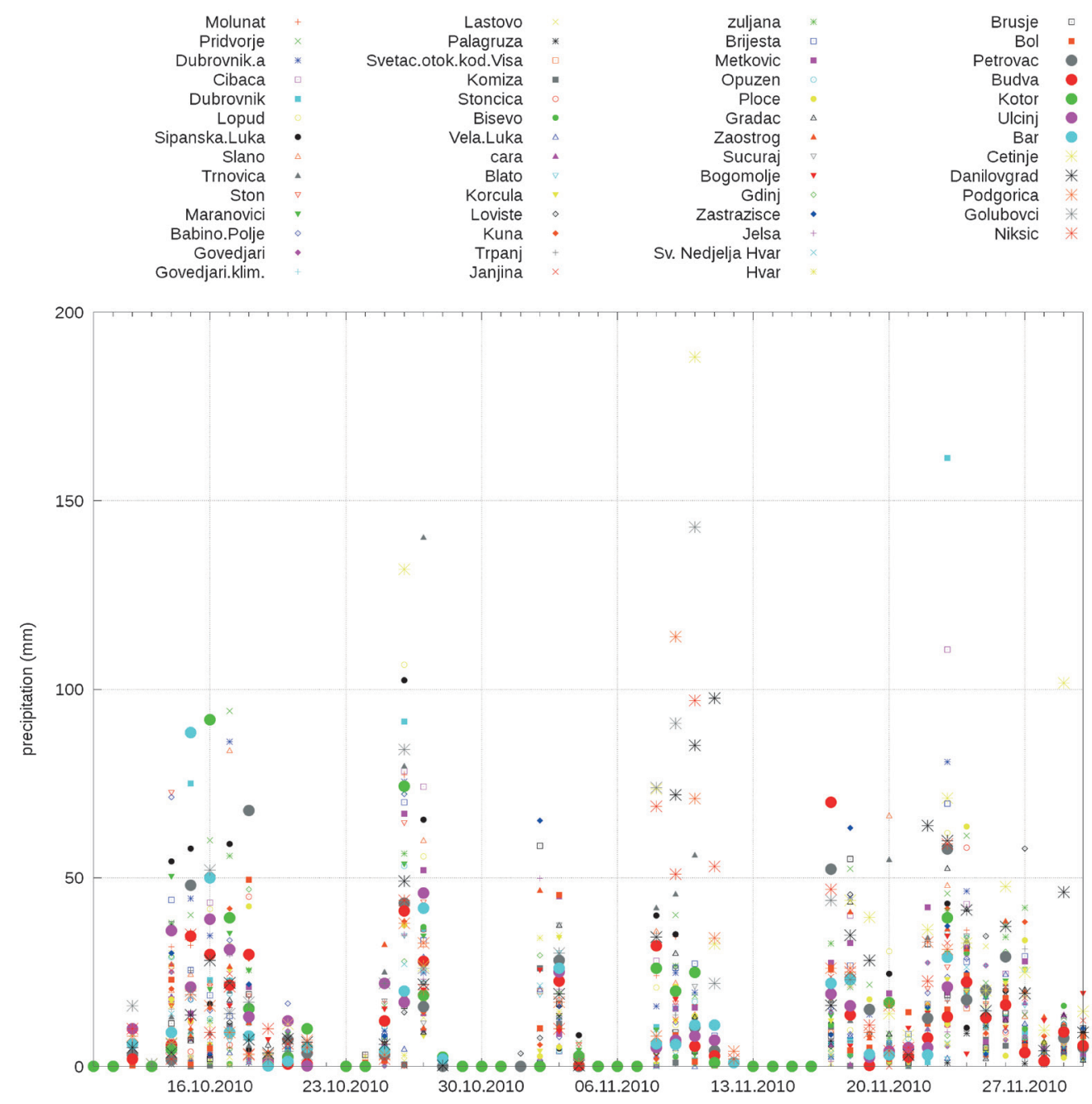

Figure 3. Measured accumulated 24 hourly precipitation on rain gauges in southeastern Croatia (smaller symbols) and Montenegro (larger symbols) during November 2010. Precipitation shown for a certain day is measured at 6 UTC accumulated from the previous 24 hours. Only stations close to Adriatic coast are shown. 
of the wind vectors in Fig. 3 indicates wind speed in $\mathrm{m} / \mathrm{s}$ ) that brought warm air and Sahara dust from the northern Africa (often found in rain gauges after intensive rainfall events), aerosols are also shown in Fig. 4. Over Adriatic, the wind was strong to severe from southwest and south direction (Fig. 3). The wind direction was well forecast by the model, but at Palagruža, Dubrovnik, Prevlaka wind speed was underestimated, while at Mljet and Biokovo the observed wind speed was correctly modelled. Pressure measurements reveal that during this event the Adriatic Sea was subject to a deep cyclone that last for several days (Fig. 2) with a strong pressure gradient over the Adriatic Sea.

The precipitation intensity was estimated using the PC and CRR fields that showed strong convection and rainfall in the afternoon and evening with periods of weak to moderate rain intensity during the night and early morning. The precipitating clouds covered much of the area, while the convective rainfall rate was far more localized and very intensive. It is important to note that PC and CRR fields were available on $6 \mathrm{~h}$ interval, while heavy rainfall could have occurred outside the sampling interval and easily could have been missed. The 24 hourly

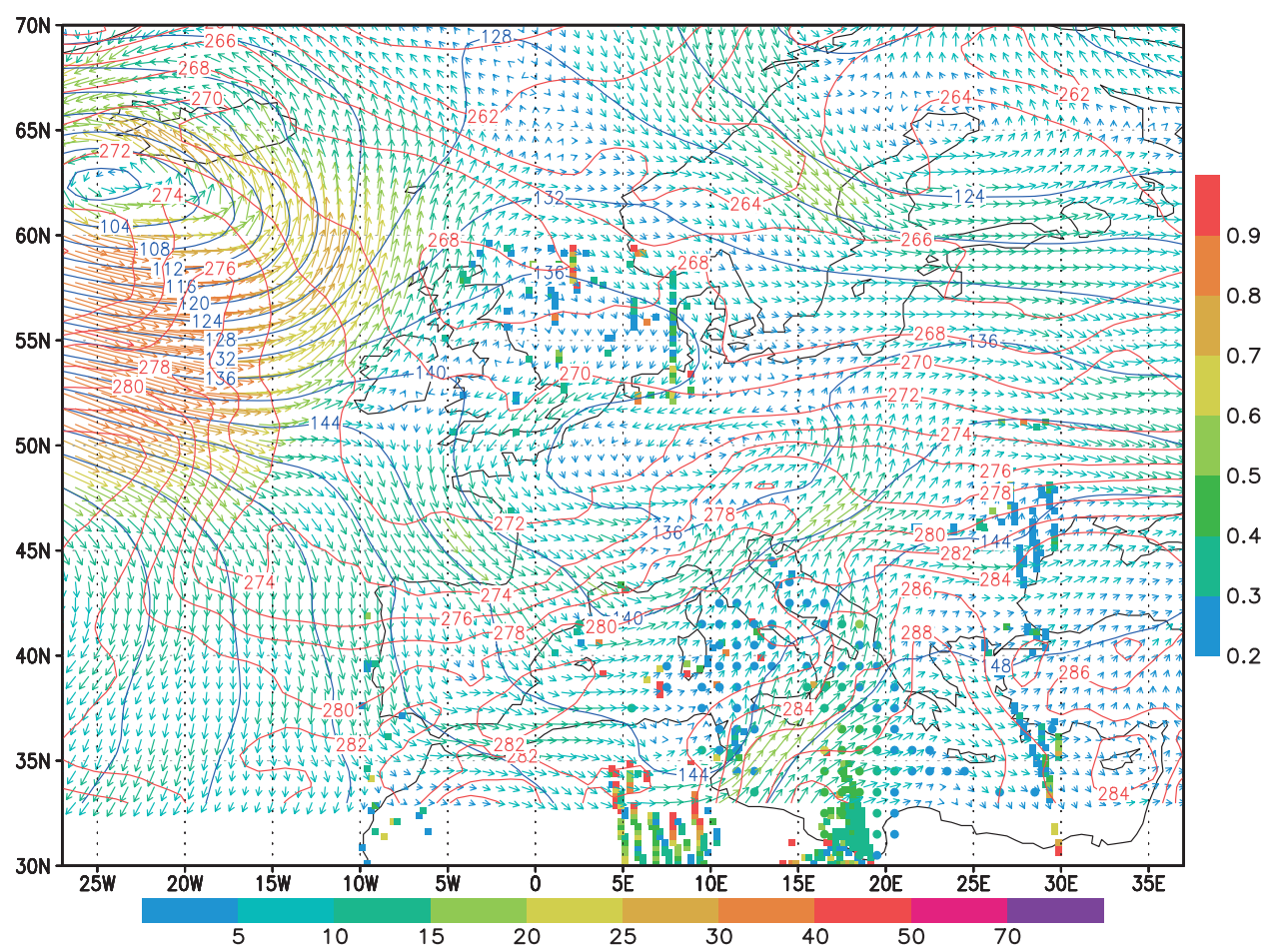

Figure 4. ERA Interim $850 \mathrm{hPa}$ wind (colour of the vectors shows wind speed in $\mathrm{m} / \mathrm{s}$ as on the colour bar below), geopotential (blue isolines) and temperature (red isolines) with measured aerosol optical depth at 12:00 UTC 7 November 2010 from MODIS (circles) and OMI (squares). AOD is shown in colour according to the colour bar on the right. 

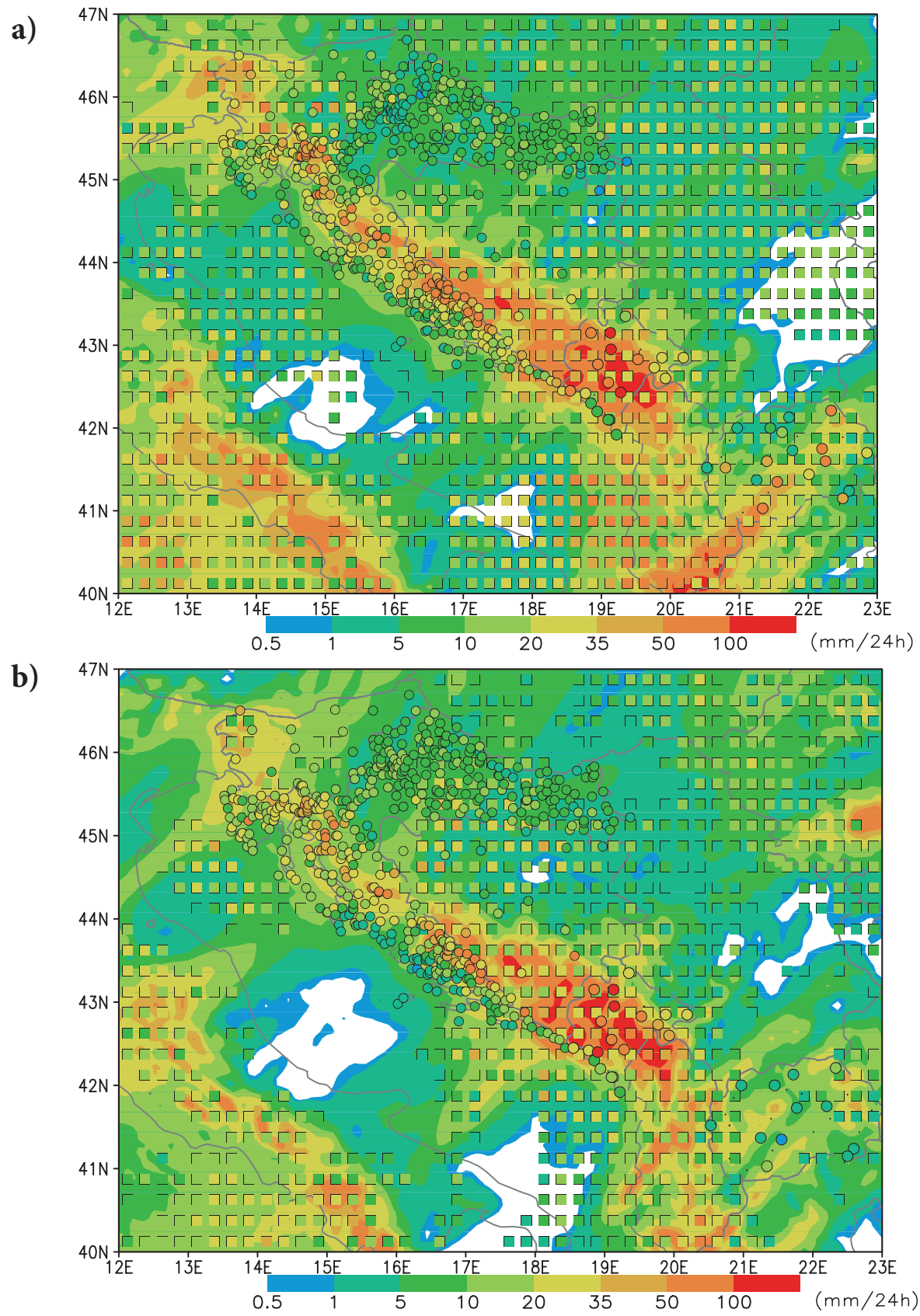

Figure 5. Measured accumulated 24 hourly precipitation on rain gauges in Croatia, Montenegro and Macedonia (circles), TRMM rainfall data (squares) and $8 \mathrm{~km}$ ALADIN forecast data (shaded background), the precipitation is accumulated for the period from 06:00 UTC on 8 until 06 UTC on 9 (top) and from 06 UTC on 9 until 06 UTC on 10 (bottom) November 2010. 


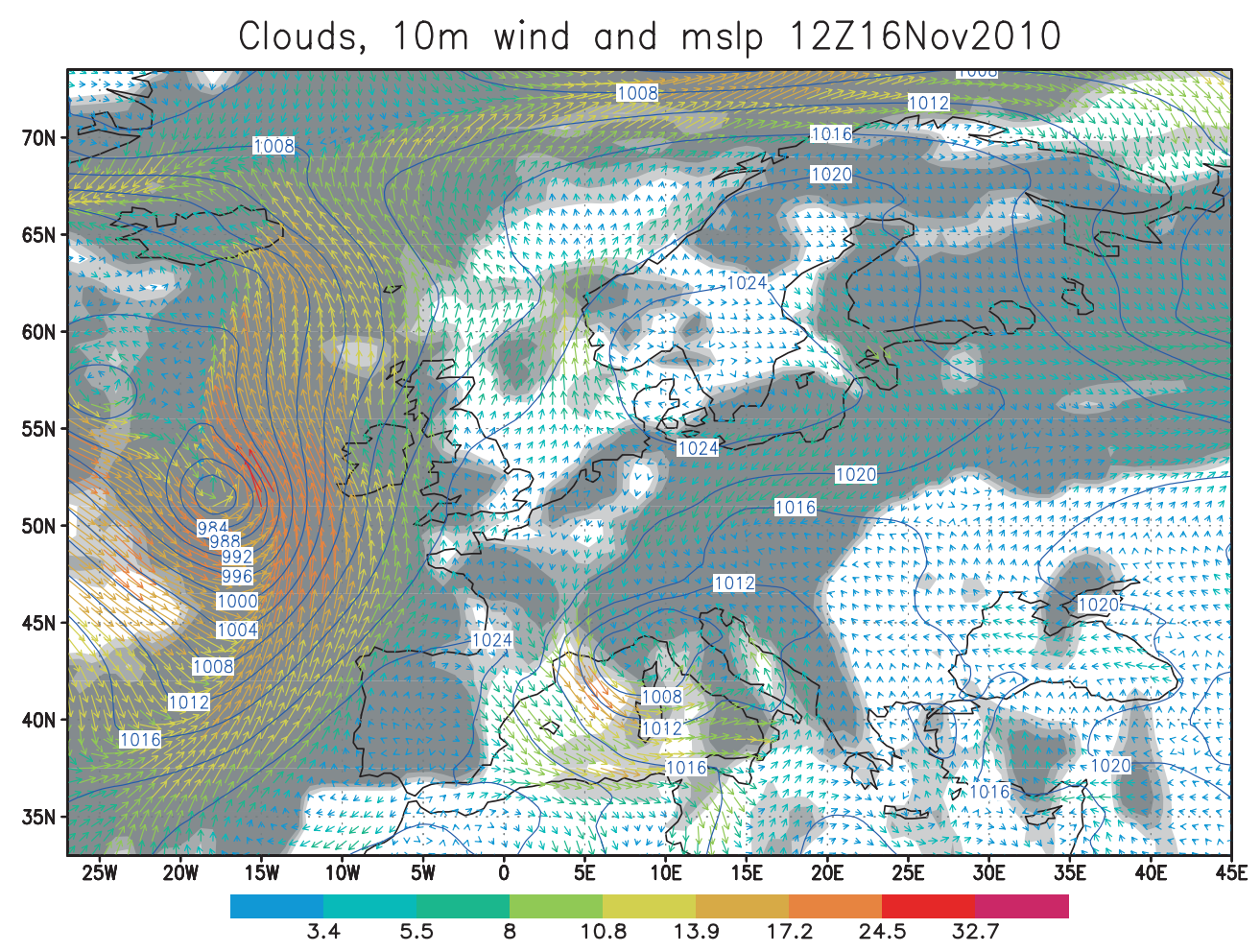

Figure 6. ERA Interim $10 \mathrm{~m}$ wind (colour of the vectors shows wind speed in $\mathrm{m} / \mathrm{s}$ as on the colour bar below), mean sea level pressure (blue isolines) and cloudiness (shades of grey for cloudiness larger than $0.4,0.6$ and 0.8 ) for 12 UTC on 16 November 2010.

precipitation exceeds $100 \mathrm{~mm}$ over parts of southeast Croatia, Bosnia and Hercegovina, Montenegro and northern Albania in TRMM precipitation estimates (shown as squares in Fig. 4) and measurements at several rain-gauges in Montenegro for two consecutive days (rain-gauge measurements are shown as circles in Fig. 5) as well as in the model forecast (shaded background in Fig. 5). Measurements from the rain-gauges showed that during E3, rainfall was the most intensive on stations in Montenegro (larger circles and stars on Fig. 3) hence on southeast Adriatic coast and significantly more intensive than in other episodes in November 2010. For example, on 10 November 2010, there was $188.1 \mathrm{~mm}$ of rain measured at Cetinje and $143 \mathrm{~mm}$ measured at Golubovci station, both in Montenegro. Accumulated precipitation data are shown on maps for 9 and 10 November 2010 (for all available stations, circles in Fig. 5). There were 3 intensive precipitation events before 21 November 2010, and measured precipitation exceeded $100 \mathrm{~mm} / 24$ hours in Montenegro only in the event 7 to 10 November 2010 (Fig. 3). TRMM data also show that 24 hourly precipitation exceeded $100 \mathrm{~mm}$ over Albania in the same event. The forecast of the accumulated 
24 hourly rainfall corresponds to the values measured on rain-gauges, although the model exaggerated slightly the rainfall on the coastline and underestimated the rainfall on several locations further inland (Fig. 5). Wind measurements (Fig. 2) show that wind in E3 episode was from south direction, more energetic and lasted longer than for other strong wind episodes during November 2010.

After E3, in the period from 11 till 15 November 2010, the weather was mostly dry with weak to moderate wind and direction typical for the sea breeze diurnal cycle (Fig. 2). In the next days a cyclone formed in the Genoa bay (15 November 2010) supporting again strong jugo wind over the whole Adriatic Sea (Fig. 2). Moreover, the wind strengthened (Fig. 2) with prevailing direction from southeast as measured in Dubrovnik, Mljet and Prevlaka (Fig. 7). Precipitation
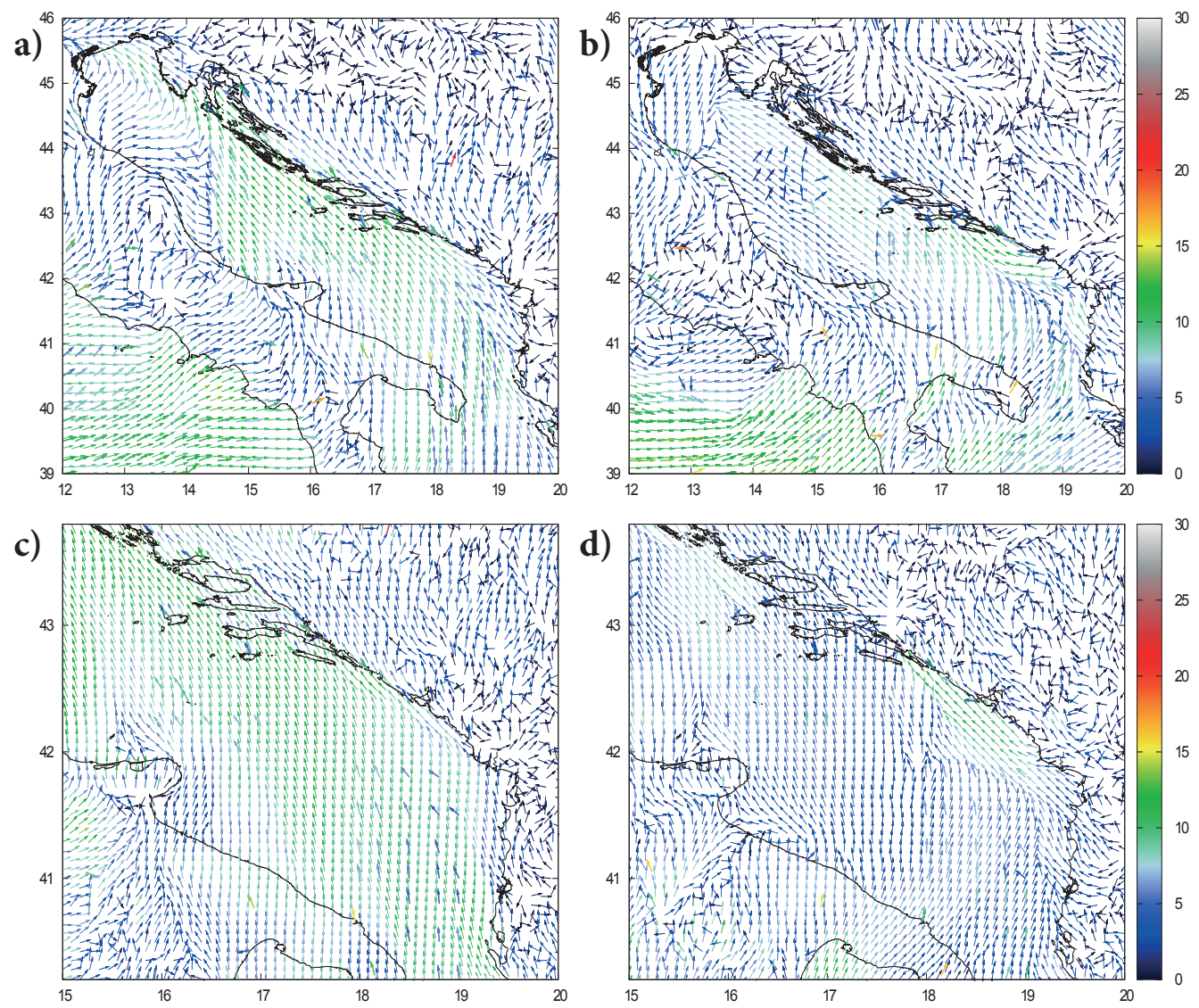

Figure 7. Forecast $10 \mathrm{~m}$ wind in $8 \mathrm{~km}$ (top) and $2 \mathrm{~km}$ (bottom) resolution and measured wind speed and direction (arrows) from Metop ASCAT data (above the sea surface), SYNOP and automatic stations for 12:00 UTC 16 (left) and 17 (right) November 2010. Colour of the vectors shows wind speed in $\mathrm{m} / \mathrm{s}$ as on the colour bars. Model data are shown as thin vectors on a denser grid in the background, measured wind is shown as thicker vectors on the location of measurement. 
was intensive with peaks above $100 \mathrm{~mm}$ within $24 \mathrm{~h}$ on 17 November (E4), but the maxima were localized on northeast Adriatic. The ALADIN model forecast had similar rainfall distribution, as a result, E4 was omitted from detailed analysis as a period favourable with respect to the flash flood. However, it is important as the wind field has driven the currents on the sea surface. During E4 wind was stronger on the eastern coast (Dubrovnik and Prevlaka) than in the off-shore region (Mljet), as a consequence of channelling effect of the coastal mountains (Fig. 7). Model yields stronger wind above open sea (thinner arrows on regular grid in Fig. 7) over southern Adriatic than Metop ASCAT wind data (thicker arrows in Fig. 7) for 16 November 2010, but the wind strength and direction are correct for 17 November 2010 (Fig. 7). The global pressure gradient over the Mediterranean and Central Europe supported the wind regime from south and southeast over the whole southern Adriatic (Fig. 6). Later, by 19 November 2010, the wind changed direction to southwest. A cyclone moved from Atlantic

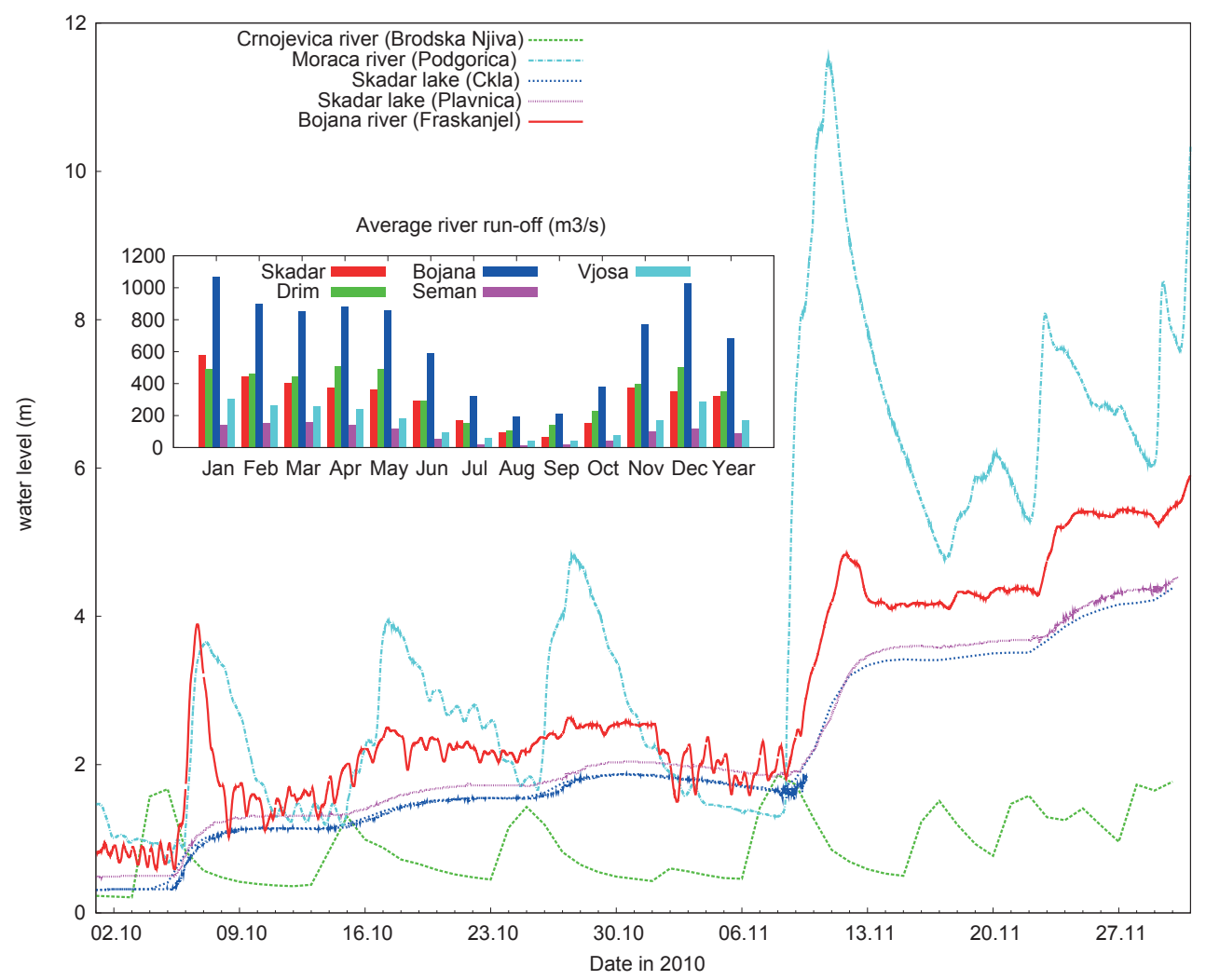

Figure 8. Measured water levels of rivers in Montenegro and Skadar Lake in October and November 2010 and climatological river run-off of Albanian rivers (embedded figure). Morača and Crnojevića rivers are tributaries to the Skadar lake, Bojana River takes the outflow from the Skadar Lake and flows into the Adriatic sea at the position marked as Bojana in Fig 1. 
southeast, to the western Mediterranean. The wind changed to strong and severe jugo wind on the 21 November 2010.

Based on the analysis of available precipitation fields, it turns out that E3 episode was the one when intensive rainfall occurred over coast and inland of southeast Adriatic and was the most likely event that could have triggered a flash flood there.

\subsection{Hydrology}

The river water level measurements on the rivers in Montenegro that belong to the Adriatic Sea catchment area (Fig. 8) increase substantially for the E3 episode. The water level surge was the most intense for the rivers that fill the Skadar Lake. The level of Bojana River raised as well during the same event. This is followed by a rise of $1.5 \mathrm{~m}$ in the water level of the Skadar Lake. Bojana River level rose before the level of Skadar Lake, this could have happened due to an increase in contribution from the Drim River tributary. The water levels of Skadar Lake and Bojana River remained high until the end of November 2010.

Those measurements suggest that the event (E3) from 8 till 10 November 2010 was capable of flushing the waste material into the Adriatic Sea or any of the rivers in the area that flow into it.

\subsection{Ocean model results}

Ocean model results show (Fig. 9) consistent development of strong surface northwest currents after strong jugo wind episodes and small eddies close to the eastern Adriatic coast in the periods of weak wind forcing. As stated before in the text, during the November 2010, we can find three periods of different wind conditions over the Adriatic Sea. The first one from 7 till 11, when strong southeast wind generated strong northwest current system in southeast Adriatic (Fig. 9a). After followed a weak wind period when the sea-current transport was weaker (Fig. 9b) and ocean model formed a pool of colder water in southeast Adriatic in the area where Bojana River enters the Adriatic Sea. Finally, the period with moderate to strong southeast wind (Fig. 9c) strengthened the northwest current. This event was most likely responsible for waste transport and later deposition.

A number of numerical drifter experiments was set in which trajectories were initiated in southeast Adriatic area on the 12:00 UTC, 19 (experiment 1) and 25 October 2010 (experiment 2), and then sequentially at 00:00 and 12:00 UTC on each day starting from 8 till 12 November 2010 (experiments 3-11). All virtual drifters were released within a polygon covering an area over southeastern Adriatic. The initial locations of virtual drifter trajectories were separated by 0.01 degree (about $1 \mathrm{~km}$ ) along longitude and latitude (in total 3071 drifters) and filled a polygon with longitude and latitude coordinates of southwest corner (19.1, 
00 GMT 11 Nov 2010
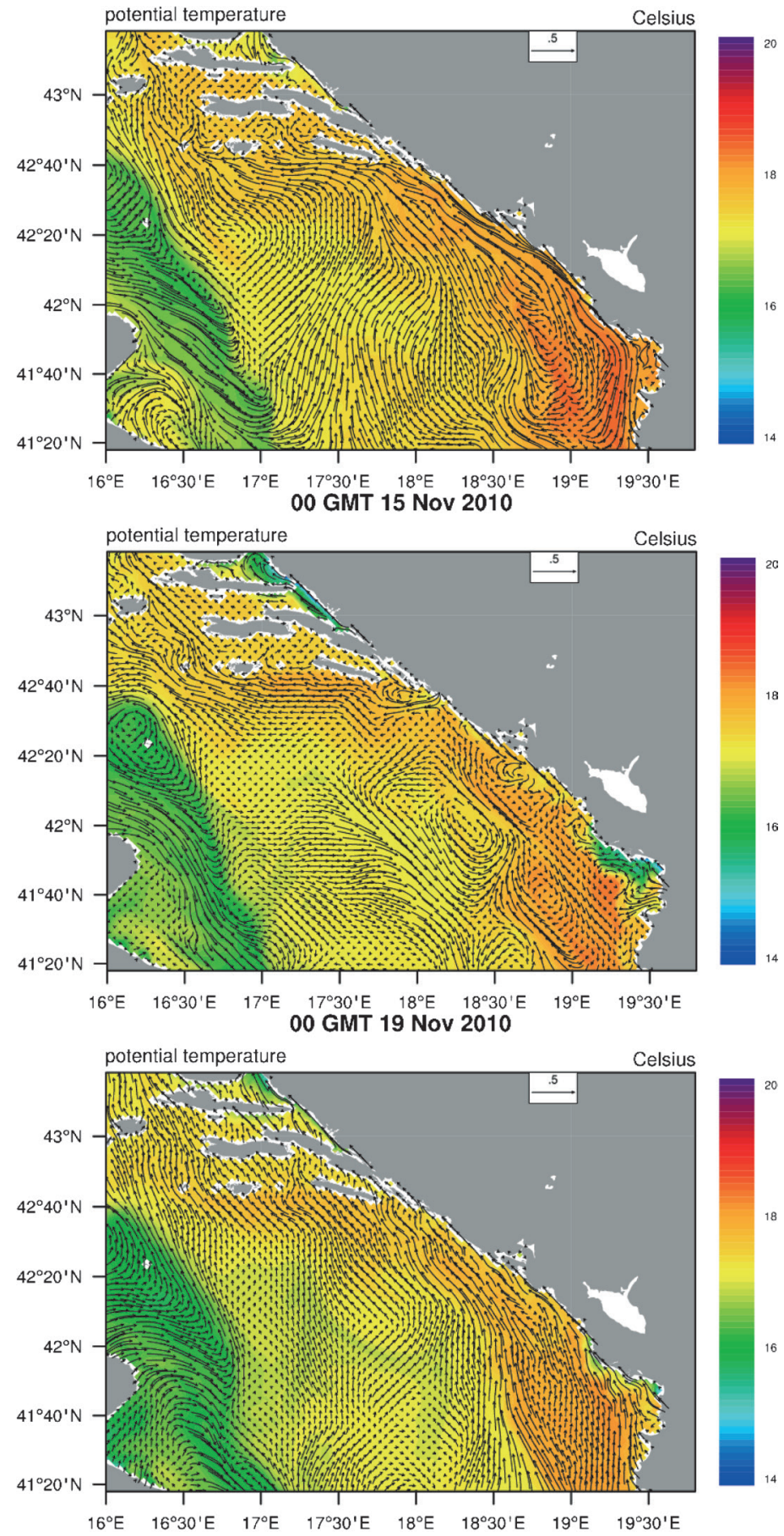

Figure 9. Surface

currents (vectors) and sea surface temperature (shaded background) from ROMS for 00:00 UTC on $11(a), 15(b)$ and 19 (c) November 2010. 
41.0) and northeast corner $(19.4,41.9)$ - a portion of southeastern Adriatic Sea in the vicinity of coast of Albania and Montenegro (Fig. 10). Furthermore, we divided the polygon into 9 areas (A1, ..., A9) to better cluster and track different subregions, hence possible source origin. The drifters starting from different areas are plotted in different colours, as marked on the Fig. 10.

A plot of drifter positions was done with 6 hourly interval for each experiment (not shown), and the summary trajectories are shown in Fig. 10.

In the experiment 1 the drifters were released at 12:00 UTC, 19 October 2010 and were first pushed offshore into EAC. It turns out that a considerable number of drifters originated from regions A7, A8 and A9 reached Croatian coast and Mljet Island already on 27 October 2010. The drifters from regions A4, A5 and

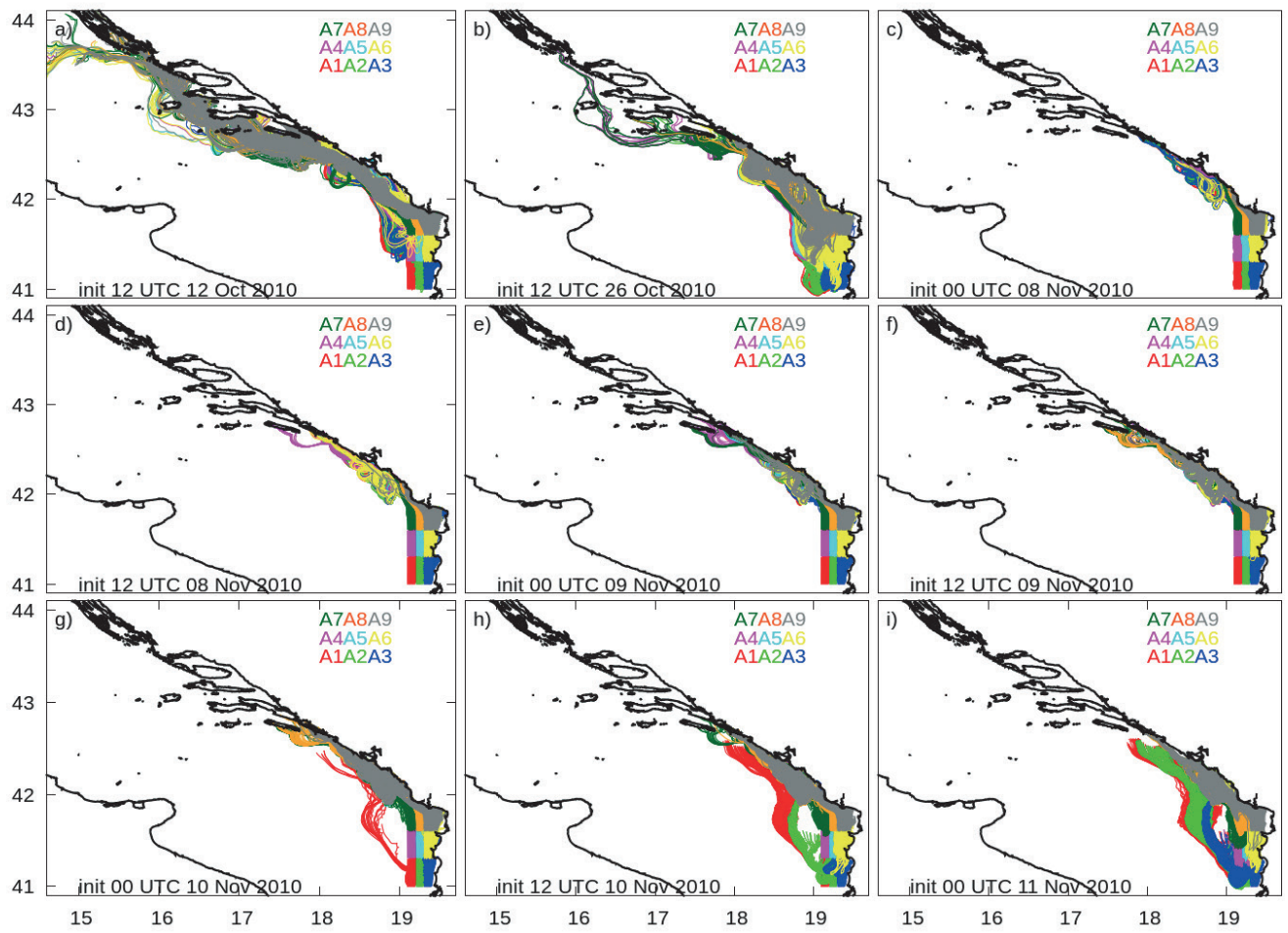

Figure 10. Trajectories of drifters released at 12:00 UTC on $19(a)$ and 26 Oct $(b), 00: 00(c)$ and 12:00 (d) UTC on 8 of Nov, 00:00 (e) and 12:00 (f) UTC on 9 of Nov, 00:00 (g) and 12:00 (h) UTC 10 of Nov and 00:00 UTC on 11 (i) Nov 2010, endpoints for all trajectories at 00:00 UTC 22 Nov 2010. Trajectories initiated off different parts of a rectangle in southeast Adriatic are plotted in different colours. The polygons are A1 (red): SW (19.1, 41.0), NE (19.2, 41.3), A2 (green): SW (19.2, 41.0), NE (19.3, 41.3), A3 (blue): SW (19.3, 41.0), NE (19.4, 41.3), A4 (magenta): SW (19.1, 41.3), NE (19.2, 41.6), A5 (cyan): SW (19.2, 41.3), NE (19.3, 41.6), A6 (yellow): SW (19.3, 41.3), NE (19.4, 41.6), A7 (dark green): SW (19.1, 41.6), NE (19.2, 41.9), A8 (orange): SW (19.2, 41.6), NE (19.3, 41.9), A9 (grey): SW $(19.3,41.6), \mathrm{NE}(19.4,41.9)$. 
A6 reached Mljet Channel by 3 November, but were pushed back southeast in the following days. Those drifters continued further to the northwest and finally accumulated on the islands much further northwest than observed (Fig. 10a). There were no reports of significant accumulation of waste on the Croatian coast that would be a consequence of this event. In that sense, we can reject the hypothesis that this rainfall event was the one that caused the flash flood that got the waste material to the sea.

For experiment 2 the drifters were released at 12:00 UTC on 26 October 2010. Soon the drifters were advected in the westward direction. When drifters entered EAC, they moved more to the northwest and were deposed on Mljet Island already on 9 November 2010. However, several drifters starting from A6 region entered Mljet Channel on 18 and later deposed on Pelješac on 21 November (Fig. 10b). Based on those results we can assume that it is possible but unlikely that the rainfall event on 26 October 2010 has initiated the chain of events that led to severe waste disposal in the region.

Drifters initiated on 8 November (both 00:00 and 12:00 UTC - experiments 3 and 4) mostly arrived to southeast Adriatic Sea coast, the northern Albania and Montenegro as soon as on the 11 November 2010 (Figs. 10c and d) as a consequence of sea current system supported by strong southern and SSW wind blowing on 8 and 9 November 2010. Furthermore, strong wind changed direction into NW on 12 and 13 November 2010 generating currents that transported numerical drifters off the coast, resulting only with a small number of them (initiated from A4 region), to reach Mljet Island and coastline northwest of Dubrovnik by 18 November 2010. The rest of the drifters dominantly stayed in the southeast region, while only a small number of them moved northeastward not entering Mljet Channel, but instead floated much closer to coast, at the end finally accumulated in the Koločep Channel and Ston bay area on 25 November 2010.

The fastest drifters initiated from A7, A4 and A8 regions at 00:00 and 12:00 UTC on 9 November 2010 (experiments 5 and 6) reached Mljet Island and entered Mljet Channel already on 17 and 18, while a majority of drifters from other areas accumulated in the Ston bay after 21 November 2010 (Figs. 10e and f, Figs. $11 \mathrm{a}$ and $\mathrm{b})$.

A small number of drifters from A7, A8 and A9 regions, released at 00:00 and 12:00 UTC on 10 November 2010 (experiments 7 and 8) reached Mljet, Dubrovnik and Koločep Channel by 18, while other drifters initiated from the same area accumulate on the Croatian shores on 21 November 2010 (Figs. 10g and h, Figs. $11 \mathrm{c}$ and d). The drifters initiated further south lagged behind former ones and approached the affected area on 22 November 2010. Those dates were reported in the media as the onset of severe pollution at the Croatian coast. Although the drifters released from the closest polygon A7 are among the first to reach the affected coast, drifters from other polygons that accompany them differ depending on the date of release. One should keep in mind that drifters released earlier at 

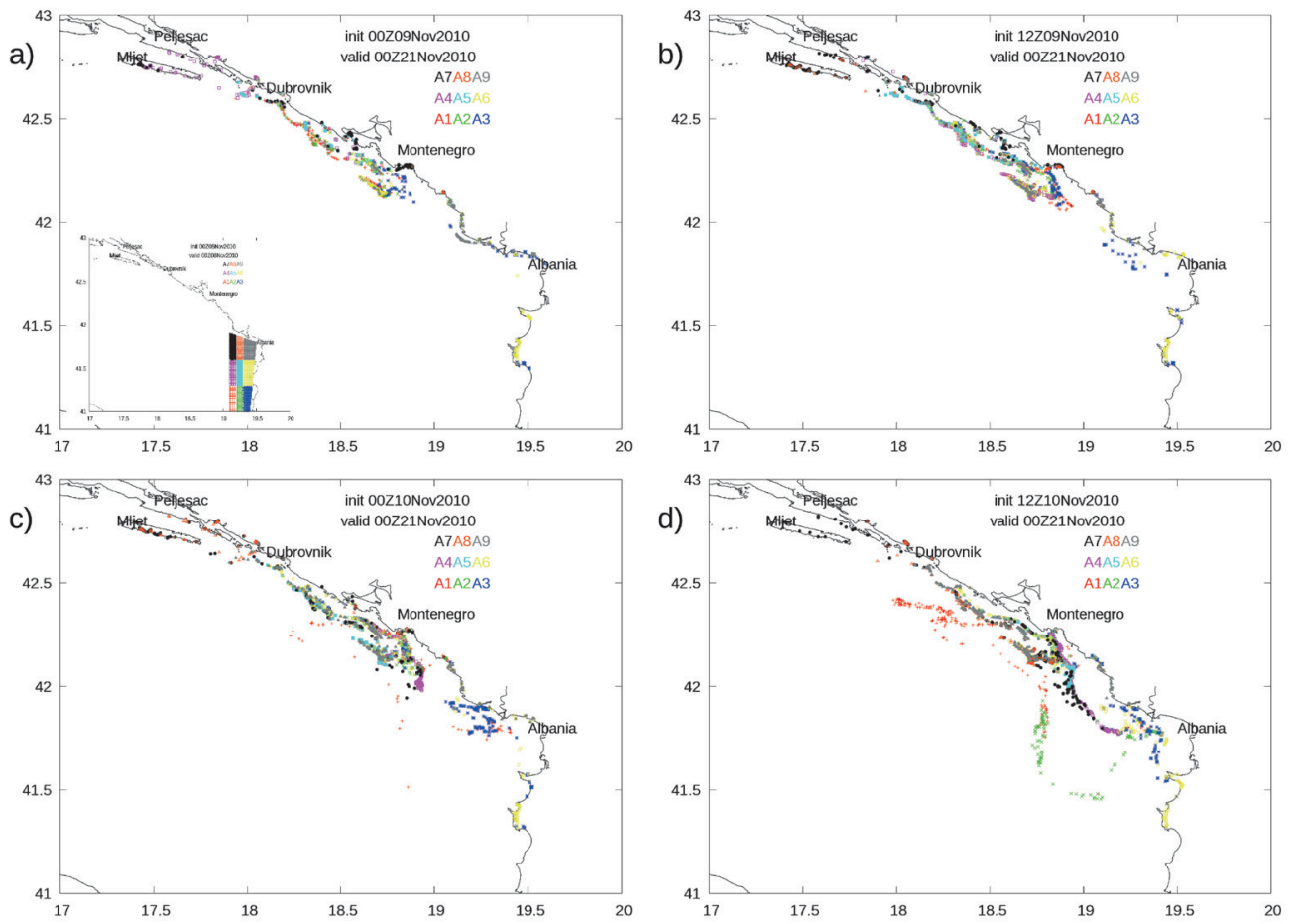

Figure 11. The positions of drifters at 00 UTC 21 Nov 2010 initiated at $00(a)$ and $12(b)$ UTC 9 and $00(c)$ and $12(d) 10$ Oct 2010. Drifters released from different polygons are drawn as different marks and in different colours: A1 (red plus), A2 (green x), A3 (blue flake), A4 (magenta empty square), A5 (cyan full square), A6 (yellow empty circle), A7 (black full circle), A8 (orange empty triangle) and A9 (grey full triangle).

distant polygons can pass through the A7 area at a later date so they follow the path of A7 drifters released at that date.

The last three sets of drifters, released at 00:00 and 12:00 UTC on 11 and 00:00 UTC on 12 November 2010 (experiments 9-11) were first pushed westward off the Albanian coast and stayed in the area off shore of Albania and Montenegro for a few days. Later they were transported into southward direction on 14 to 16 November 2010 (Fig. 10i). Apparently, EAC was detached, at that time, from the shore and it's typical path. As a result, drifters from A1 and A2 regions arrived further northwestward than drifters initiated more to the north or closer to the coastline.

Consequently, drifter paths indicate that garbage reaching Pelješac and Mljet mostly originated from locations offshore, while drifters starting close the coast moved northwestward, but remain close to the coast. This could be attributed to inability of numerical model to generate currents which transport garbage from the coast, possible absence of wind (in the model fields) that would 
generate such currents or EAC detachment. The absence of measured river discharges from Albania and forcing the ocean model with climatological river data could be another cause of the problem.

\section{Discussion and conclusions}

The oceanographic and meteorological conditions that lead to a severe deposition of waste material on the southeastern Adriatic Sea coast on 21 November 2010, are studied using ALADIN - meteorological and ROMS - ocean numerical models along with available measurements. We tried to answer what, where and when was the cause for the event. The initial points presented in this study were limited to the area of southeast Adriatic since the labels indicated that some of the items possibly originate from Albania as well the cyclonic Adriatic circulation is the major current feature responsible for surface transport.

Based on the meteorological simulations and satellite derived precipitation we identified several intensive rainfall events that could have initiated flash floods in Albania and presumably flush the waste material to the rivers and later to the Adriatic Sea. Moreover, measured and NWP model rainfall data shows that the rain was more intensive over the Albania in the event from 8 till 10 November 2010 (E3) than in the other intensive rainfall events that occurred in the studied area during the 4 weeks before the reported waste accumulation.

Measured wind speed during the episode E3 was strong to severe from southern direction, however slightly underestimated by the operational ALADIN model forecast at several coastal locations. Improvements in the atmospheric model resolution could resolve those issues as noted in Signell et al. (2005). Since strong wind influences the surface currents that advect the drifters, this could have an impact on the computed trajectories of virtual drifters. It is interesting to note that based on the ASCAT estimated wind data, for the 16 November 2010, ALADIN model wind speed was stronger than the measured one (Fig. 7). During the last studied period (E4), wind from observations, as well from the model, indicates southeast direction with weaker magnitudes than during the E3 period. In the E4 case the strongest wind was found over the open sea, in the southeast region of Mljet Island as well south of Dubrovnik (Fig. 7). This event is a typical jugo wind episode which further enhanced the sea surface current system - responsible for transport of the waste material towards the Croatian waters and finally to the accumulation on the shore at 21 November 2010.

One should bear in mind that the drifter trajectories do not allow us to assign a single event in space and time as the moment when the waste was disposed to the sea. There is ambiguity in the position as a result of unresolved physics, imperfect meteorological model and initial conditions used to force the ocean counterpart, missing dynamics in the ocean model introduced with a lack of wavecurrent interaction, spatial model resolutions in the narrow channels etc. 
However, the results do show that there is a possibility and that it is the most probably that the heavy rain occurred during 9 and 10 November 2010 washed the waste into the sea (or first to a river that carried it to the sea by that date). The computations further show that not all the numerical drifters initiated in southeast Adriatic inevitably ended on the coastline of southeast Croatia. Although initiated during the same event, drifters from different polygons reach the affected coastline depending on the time of release (Fig. 11). The drifters do not disperse over the sea surface and actually cover smaller area on 21 Nov 2010 than when released (Fig. 11). This allows substantial accumulation of waste on certain parts of coastline, while other could remain unaffected. Surface sea currents enhanced by the wind forcing can carry the waste back to the shore, or to the closer coastline of Montenegro. Otherwise, different meteo-ocean conditions can push the waste off shore, and EAC can carry the waste to central or even north Adriatic, or in some cases back to the southern regions of the Adriatic Sea. However, none of the trajectories initiated in our experiments crossed the Adriatic Sea and approached to Italy, which is probably due to an absence of intensive bura events during the studied period.

There are possibilities of garbage arriving from Otranto, or even from the western Adriatic coast via the south Adriatic cyclonic gyre. Given the above uncertainties, we focused on the sources nearby and the most intuitive scenarios. The model and remote sensing data indicate more rainfall over Albania than Montenegro for E3 episode (as well as other dates). The absence of in-situ data from Albania, for both - precipitation and river discharges, prevents us from drawing more definite conclusions, as well as forcing the ocean model with observed river discharges rather than climatological data.

Acknowledgements - The authors would like to thank the Meteorological and Hydrological Service of Montenegro for providing the meteorological and water level measurements as well AREG - INGV, Bologna, Italy. The authors are grateful to NASA for providing valuable satellite derived products through the GIOVANNI web interface as well as TRMM, OMI and MODIS scientists and developers. The NOAA NESDIS CoastWatch and NOAA SWFSC ERD are acknowledged for providing Metop ASCAT wind data. Dr. I. Janeković was sponsored through project ADAM-ADRIA - 5928 of Croatian Science Foundation. Martina Tudor thanks the Croatian Ministry of Science for support through the grant 004-1193086-3036. The authors also thank two anonymous reviewers, their comments improved the manuscript substantially.

\section{References}

Acker, J. G. and Leptoukh, G. (2007): Online analysis enhances use of NASA Earth science data, Eos Trans. $A G U, 88,14-17$, DOI: 10.1029/2007EO020003.

ALADIN International Team (1997): The ALADIN project: Mesoscale modelling seen as a basic tool for weather forecasting and atmospheric research, WMO Bull., 46, 317-324.

Alpert, P., Neeman, B. U. and Shay-El, Y. (1990): Intermonthly variability of cyclone tracks in the Mediterranean, J. Climate, 3, 1474-1478, DOI: 10.1175/1520-0442(1990)003<1474:IVOCTI>2.0.CO;2. 
Artegiani, A., Bregant, D., Paschini, E., Pinardi, N., Raicich, F. and Russo, A. (1997): The Adriatic Sea general circulation, Part II: Baroclinic circulation structure, J. Phys. Oceanogr., 27, 15151532, DOI: 10.1175/1520-0485(1997)027<1515:TASGCP>2.0.CO;2.

Bajić, A., Ivatek-Šahdan, S. and Horvath, K. (2007): Spatial distribution of wind speed in Croatia obtained using the ALADIN model, Cro. Met. J., 42, 67-77.

Beg Paklar, G., Žagar, N., Žagar, M., Vellore, R., Koračin, D., Poulain, P.-M., Orlić, M., Vilibić, I. and Dadić, V. (2008): Modeling the trajectories of satellite-tracked drifters in the Adriatic Sea during a summertime bora event, J. Geophys. Res., 113, C11S04, DOI:10.1029/2007JC004536.

Bentamy, A. and Croizé-Fillon, D. (2012): Gridded surface wind fields from Metop/ASCAT measurements, Int. J. Remote Sens., 33, 1729-1754, DOI: 10.1080/01431161.2011.600348.

Bentamy, A., Grodsky, S. A., Carton, J. A., Croizé-Fillon, D. and Chapron, B. (2012): Matching ASCAT and QuikSCAT winds, J. Geophys. Res., 117, C02011, DOI: 10.1029/2011JC007479.

Branković, C., Matjačić, B., Ivatek-Šahdan, S. and Buizza, R. (2008): Downscaling of ECMWF ensemble forecasts for cases of severe weather: Ensemble statistics and cluster analysis, Mon. Weather Rev., 136, 3323-3342, DOI: 10.1175/2008MWR2322.1.

Brzović, N. (1999): Factors affecting the Adriatic cyclone and associated windstorms, Contr. Atmos. Phys., 72, 51-65.

Brzović, N. and Strelec Mahović, N. (1999): Cyclonic activity and severe jugo in the Adriatic, Phys. Chem. Earth, 24, 653-657, DOI: 10.1016/S1464-1909(99)00061-1.

Burrage, D., Wesson, J., Martinez, C., Pérez, C., Möller, O. and Piola, A. (2008): Patos Lagoon outflow within the Río de la Plata plume using an airborne salinity mapper: Observing an embedded plume, Cont. Shelf. Res., 28, 1625-1638, DOI: 10.1016/j.csr.2007.02.014.

Burrage, D. M., Book, J. W. and Martin, P. J. (2009): Eddies and filaments of the Western Adriatic Current near Cape Gargano: Analysis and prediction, J. Marine Syst., 78, 205-226, DOI: 10.1016/j.jmarsys.2009.01.024.

Carr, S. D., Capet, X. J., McWilliams, J. C., Pennington, J. T. and Chavez, F. P. (2008): The influence of diel vertical migration on zooplankton transport and recruitment in an upwelling region: Estimates from a coupled behavioral-physical model. Fish. Oceanogr., 17, 1-15, DOI: 10.1111/j.1365-2419.2007.00447.x.

Cassou, C. and Terray, L. (2001): Oceanic forcing of the wintertime low-frequency atmospheric variability in the north atlantic european sector: a study with the arpege model, J. Climate, 14, 42664291, DOI: 10.1175/1520-0442(2001)014<4266:OFOTWL>2.0.CO;2.

Cushman-Roisin, B., Gačić, M., Poulain, P.-M. and Artegiani, A. (2001): Physical Oceanography of the Adriatic Sea. Kluwer Academic Publishers, Dordrecht., 304 pp.

Dee, D. P., Uppala, S. M., Simmons, A. J., Berrisford, P., Poli, P., Kobayashi, S., Andrae, U., Balmaseda, M. A., Balsamo, G., Bauer, P., Bechtold, P., Beljaars, A. C. M., van de Berg, L., Bidlot, J., Bormann, N., Delsol, C., Dragani, R., Fuentes, M., Geer, A. J., Haimberger, L., Healy, S. B., Hersbach, H., Hólm, E. V., Isaksen, L., Kàllberg, P., Köhler, M., Matricardi, M., McNally, A. P., Monge-Sanz, B. M., Morcrette, J.-J., Park, B.-K., Peubey, C., de Rosnay, P., Tavolato, C., Thépaut, J.-N. and Vitart, F. (2011): The ERA-Interim reanalysis: Configuration and performance of the data assimilation system, Q. J. Roy. Meteor. Soc., 137, 553-597, DOI: 10.1002/qj.828.

Döös, K., Rupolo, V. and Brodeau, L. (2011): Dispersion of surface drifters and model-simulated trajectories, Ocean Model., 39, 3-4, 301-310, DOI: 10.1016/j.ocemod.2011.05.005.

Dorman, C., Book, J., Carniel, S., Cavaleri, L., Chiggiato, J., Doyle, J., Grbec, B., Haack, T., Janeković, I., Lee, C., Malacic, V., Orlić, M., Pullen, J., Russo, N., Paschini, E., Sclavo, M. and Vilibić, I. (2006): Winter 2003 marine atmospheric conditions and the Bora over the Northern Adriatic, J. Geophys. Res., 111, C03S03, DOI: 10.1029/2005JC003134.

Geleyn, J.-F. (1988): Interpolation of wind, temperature and humidity values from model levels to the height of measurement, Tellus A, 40, 347-351, DOI: 10.1111/j.1600-0870.1988.tb00352.x. 
Grisogono, B. and Belušić, D. (2009): A review of recent advances in understanding the meso- and microscale properties of the severe Bora wind, Tellus A, 61, 1-16, DOI: 10.1111/ j.1600-0870.2008.00369.x.

Horton, C., Clifford, M., Schmitz, J. and Kantha, L. H. (1997): A real-time oceanographic nowcast/ forecast system for the Mediterranean Sea, J. Geophys. Res., 102, 25123-25156, DOI: 10.1029/ 97JC00533.

Horvath, K., Lin, Y.-H. and Ivančan-Picek, B. (2008): Classification of cyclone tracks over the Apennines and the Adriatic Sea, Mon. Weather Rev., 136, 2210-2227, DOI: 10.1175/ 2007MWR2231.1.

Horvath, K., Ivatek-Šahdan, S., Ivančan-Picek, B. and Grubišić, V. (2009): Evolution and structure of two severe cyclonic bora events: Contrast between the northern and southern Adriatic, Weather Forecast., 24, 946-964.

Horvath, K., Bajić, A. and Ivatek-Šahdan, S. (2011): Dynamical downscaling of wind speed in complex terrain prone to bora-type flows, J. Appl. Meteorol. Climatol., 50, 1676-1691. DOI: 10.1175/ 2011JAMC2638.1.

Huffman, G. J., Bolvin, D. T., Nelkin, E. J., Wolff, D. B., Adler, R. F., Gu, G., Hong, Y., Bowman, K. P. and Stocker, E. F. (2007): The TRMM Multisatellite Precipitation Analysis (TMPA): Quasi-global, multiyear, combined-sensor precipitation estimates at fine scales, J. Hydrometeorol., 8, 38-55, DOI: $10.1175 / J H M 560.1$.

Ivatek-Šahdan, S. and Tudor, M. (2004): Use of high-resolution dynamical adaptation in operational suite and research impact studies, Meteorol. Z., 13, 1-10.

Janeković, I., Dutour Sikirić, M. A., Tomažić, I. and Kuzmić, M. (2010): Hindcasting the Adriatic Sea surface temperature and salinity: A recent modeling experience, Geofizika, 27, 85-100.

Jurčec, V., Ivančan-Picek, B., Tutiš, V. and Vukičević, V. (1996): Severe Adriatic jugo wind, Meteorol. Z., 5, 67-75.

Koren, I., Altaratz, O., Remer, L. A., Feingold, G., Martins, J. V. and Heiblum, R. H. (2012): Aerosolinduced intensification of rain from the tropics to the midlatitudes, Nat. Geosci., 5, 118-122, DOI: 10.1038/ngeo1364.

Kuzmić, M., Janeković, I., Book, J. W., Martin, P. J. and Doyle, J. D. (2006): Modeling the northern Adriatic double-gyre response to intense bora wind: A revisit, J. Geophys. Res.-Oceans, 111, C03S12, DOI: 10.1029/2005JC003377.

Lionello, P., Bhend, J., Buzzi, A., Della-Marta, P. M., Krichak, S. O., Jansà, A., Maheras, P., Sanna, A., Trigo, I. F. and Trigo, R. (2006): Cyclones in the Mediterranean region: climatology and effects on the environment, in: Mediterranean Climate Variability, edited by Lionello, P., MalanotteRizzoli, P. and Boscolo, R., Elsevier, 325-372.

Liu, Y., and Weisberg R. H. (2011): Evaluation of trajectory modeling in different dynamic regions using normalized cumulative Lagrangian separation, J. Geophys. Res., 116, C09013, DOI:10.1029/2010JC006837.

Magaš, D. (2002): Natural-geographic characteristics of the Boka Kotorska area as the basis of development, Geoadria, 7/1, 51-81.

Mesinger, F. and Strickler, R. F. (1981): Effect of mountains on Genoa cyclogeneses, J. Meteorol. Soc. Jpn., 60, 326-337.

Montenegro, A., Avis, C. and Weaver, A. J. (2008): Modelling the pre-historic arrival of the sweet potato in Polynesia, J. Archaeol. Sci., 35, 355-367, DOI: 10.1016/j.jas.2007.04.004.

Orlić, M., Kuzmić, M. and Pasarić Z. (1994): Response of the Adriatic Sea to the bora and sirocco forcing, Cont. Shelf Res., 14, 91-116, DOI: 10.1016/0278-4343(94)90007-8.

Orlić, M., Dadić, V., Grbec, B., Leder, N., Marki, A., Matić, F., Mihanović, H., Beg Paklar, G., Pasarić, M., Pasarić, Z. and Vilibić, I. (2007): Wintertime buoyancy forcing, changing seawater properties 
and two different circulation systems produced in the Adriatic, J. Geophys. Res.-Oceans, 112, C03S07, DOI: 10.1029/2005JC003271.

Pasarić, Z., Belušić, D. and Klaić, Z. B. (2007): Orographic influences on the Adriatic sirocco wind, Ann. Geophys.-Italy, 25, 1263-1267.

Poulain, P.-M., Mauri, E. and Ursella, L. (2004): Unusual upwelling event and current reversal off the Italian Adriatic coast in summer 2003, Geophys. Res. Lett., 31, L05303, DOI: 10.1029/ 2003GL019121.

Pullen, J., Doyle, J. D., Hodur, R., Ogston, A., Book, J. W., Perkins, H. and Signell, R. (2003): Coupled ocean-atmosphere nested modeling of the Adriatic Sea during winter and spring 2001, J. Geophys. Res., 108, 3320, DOI: 10.1029/2003JC001780.

Remer, L. A., Kleidman, R. G., Levy, R. C., Kaufman, Y. J., Tanré, D., Matoo, S., Vanderlei Martins, J., Ichoku, C., Koren, I., Yu, H. and Holben, B. N. (2008): Global aerosol climatology from MODIS satellite sensors, J. Geophys. Res., 113, D14S07, DOI:10.1029/2007JD009661.

Rodriguez, A. and Marcos, C. (2012): Product user manual for the "convective rainfall rate" (CRR PGE05 v3.1.1), NWC SAF and AEMET, available at: http://www.nwcsaf.org (last access: 22 March 2012), 32 pp.

Shchepetkin, A. F. and McWilliams, J. C. (2005): The regional ocean modelling system: A split-explicit, free-surface, topography-following-coordinate oceanic model, Ocean Model., 9, 347-404, DOI: 10.1016/j.ocemod.2004.08.002.

Signell, R. P., Carniel, S., Cavaleri, L., Chiggiato, J., Doyle, J. D., Pullen, J., and Sclavo, M. (2005): Assessment of wind quality for oceanographic modelling in semi-enclosed seas, J. Marine Syst., $\mathbf{5 3}, 217-233$.

Smolarkiewicz, P. K. and Margolin, L. G. (1998): MPDATA: A finite-difference solver for geophysical flows, J. Comput. Phys., 140, 459-480, DOI: 10.1006/jcph.1998.5901.

Stanešić, A. (2011): Assimilation system at DHMZ: Development and first verification results, Cro. Met. Jour., 44/45, 3-17.

Termonia, P. (2008): Scale-selective digital filter initialization, Mon. Weather Rev., 136, 5246-5255, DOI: $10.1175 / 2008$ MWR2606.1.

Thoss, A. (2012): Product user manual for SAFNWC/MSG "precipitating cloud" (PC - PGE04 v1.5), NWC SAF and SMHI, available at: http://www.nwcsaf.org/(last access: 22 March 2012), 18 pp.

Torres, O., Decae, R., Veefkind, J. P. and De Leeuw, G. (2002): OMI aerosol retrieval algorythm, clouds, aerosols and surface UV irradiance, edited by Stammes, P., Vol. III, Version 2.0.

Tudor, M. and Ivatek-Šahdan, S. (2010): The case study of bura of 1 and 3 February 2007, Meteorol. Z., 19, 453-466, DOI: 10.1127/0941-2948/2010/0475.

Tudor, M. and Termonia, P. (2010): Alternative formulations for incorporating lateral boundary data into limited area models, Mon. Weather Rev., 138, 2867-2882, DOI: 10.1175/2010MWR3179.1.

Veihelmann, B., Levelt, P. F., Stammes, P., and Veefkind, J. P. (2007): Simulation study of the aerosol information content in OMI spectral reflectance measurements, Atmos. Chem. Phys., 7, 31153127, DOI: 10.5194/acp-7-3115-2007.

Wolf, J. and Luksch, J. (1887): Bericht an die Seebehörde in Fiume über die Vorexpedition Nautilus im Sommer 1874 zum Zwecke physikalischer Untersuchungen des adriatischen Meeres. I, Bericht, Fiume, 55 pp.

Zaninović, K., Gajić-Čapka, M., Perčec Tadić, M., Vučetić, M., Milković, J., Bajić, A., Cindrić, K., Cvitan, L., Katušin, Z., Kaučić, D., Likso, T., Lončar, E., Lončar, Z., Mihajlović, D., Pandzić, K., Patarčić, M., Srnec, L., Vučetić, V. (2008): Climate Atlas of Croatia: 1961-1990: 1971-2000. CMHS Monograph, Zagreb, 200 pp. 
SAŽETAK

\section{Modeliranje izvora i transporta zagađenja na jugoistočnu obalu Jadrana (Hrvatska)}

\section{Martina Tudor i Ivica Janeković}

U ovom radu analizirali smo meteorološke i oceanografske uvjete koji su mogli doprinijeli nakupljanju otpada na jugoistočnoj obali Jadrana tijekom druge polovice studenog 2010. Pritom smo koristili dostupna mjerenja, produkate modela te daljinska mjerenja. Mjereni meteorološki podaci ukazuju na period intenzivne oborine nad područjem Albanije i Crne Gore, u period od 7. do 10. studenog 2010. Nakon događaja uslijedio je značajan porast razine lokalnih rijeka. Upravo ovaj podatak ukazuje na mogućnost bujičnih poplava koje su mogle navedeni otpad odnjeti u rijeke i zatim u Jadran (ili izravno u Jadran). Također je opaženo da su površinske morske struje, povoljne za transport otpada do hrvatske obale, bile intenzivnije usljed jakog vjetra iz smjera jugoistoka. U svrhu provjere navedenih hipoteza proveli smo niz numeričkih eksperimenata pomoću numeričkih driftera simuliranih na području jugoistočnog Jadrana, upravo tijekom perioda s opaženom jakom oborinom, a čije smo putanje računali u prostoru i vremenu. Eksperimenti s putanjama koje su stigle do traženog područja (jugoistočna obala Jadrana) u pravom vremenskom trenutku (kada je zabilježeno nakupljanje otpada) započele su gibanje u 00 i 12 UTC 10. studenog 2010, upravo tijekom spomenutog događaja s velikom količinom oborine.

Ključne riječi: Jadran, putanje driftera, numerički modeli, bujična poplava

Corresponding author's address: Martina Tudor, Meteorological and Hydrological Service of Croatia, Grič 3, HR-10000 Zagreb, Croatia; tel: +385 14565 721; fax: + 38514565 630; e-mail: tudor@cirus.dhz.hr 
